\title{
Correction to "Evidence for asymmetric nonvolcanic rifting and slow incipient oceanic accretion from seismic reflection data on the Newfoundland margin"
}

Donna J. Shillington, W. Steven Holbrook, Harm J. A. Van Avendonk, Brian E. Tucholke, John R. Hopper, Keith E. Louden, Hans Christian Larsen, and Gregory T. Nunes

Received 26 September 2006; published 9 December 2006.

Citation: Shillington, D. J., W. S. Holbrook, H. J. A. Van Avendonk, B. E. Tucholke, J. R. Hopper, K. E. Louden, H. C. Larsen, and G. T. Nunes (2006), Correction to "Evidence for asymmetric nonvolcanic rifting and slow incipient oceanic accretion from seismic reflection data on the Newfoundland margin,' J. Geophys. Res., 111, B12403, doi:10.1029/2006JB004769.

[1] In the paper "Evidence for asymmetric nonvolcanic rifting and slow incipient oceanic accretion from seismic reflection data on the Newfoundland margin" by Donna J. Shillington, W. Steven Holbrook, Harm J. A. Van Avendonk, Brian E. Tucholke, John R. Hopper, Keith E. Louden, Hans Christian Larsen, and Gregory T. Nunes (Journal of Geophysical Research, 111, B09402, doi:10.1029/ 2005JB003981, 2006), the last sentence of section 7 should be changed as follows:
[2] Finally, the variable appearance and fault geometries within apparent oceanic basement on the Newfoundland margin suggest extension and an intermittent magma supply during the transition from nonvolcanic rifting to slow incipient oceanic accretion, similar to what is observed on adjacent SCREECH transects [Funck et al., 2003; Hopper et al., 2004; Lau et al., 2006a, 2006b]. 